\title{
EchoGéo
}

$23 \mid 2013$

Entre l'ancien et le nouveau monde. La transcendance du lieu et de l'espace en géographie vinicole contemporaine

\section{'Quality' as a governmental rationality in New Zealand wine}

\author{
Russell Prince et Nicolas Lewis
}

URL : https://journals.openedition.org/echogeo/13349

DOI : $10.4000 /$ echogeo. 13349

ISSN : 1963-1197

Éditeur

Pôle de recherche pour l'organisation et la diffusion de l'information géographique (CNRS UMR 8586)

Référence électronique

Russell Prince et Nicolas Lewis, "'Quality' as a governmental rationality in New Zealand wine», EchoGéo [En ligne], 23 | 2013, mis en ligne le 05 juin 2013, consulté le 10 août 2021. URL : http:// journals.openedition.org/echogeo/13349; DOI : https://doi.org/10.4000/echogeo.13349

Ce document a été généré automatiquement le 10 août 2021.

EchoGéo est mis à disposition selon les termes de la licence Creative Commons Attribution - Pas d'Utilisation Commerciale - Pas de Modification 4.0 International (CC BY-NC-ND) 


\title{
'Quality' as a governmental rationality in New Zealand wine
}

\author{
Russell Prince et Nicolas Lewis
}

\section{Introduction}

1 When in 2003 Christchurch based entrepreneurs Robin Mundy and Brent Rawstron began exporting bulk shipments of cheap Marlborough Sauvignon Blanc destined for British supermarket shelves packaged in three litre casks (Tipples, 2008), the initiative was widely portrayed as a threat to New Zealand's quality image. The media played host to a polarising debate over whether the initiative was an innovative strategy or the inevitable but short-sighted exploitation of the collectively earned but unprotected economic rents generated by Marlborough's hard-won reputation as a world-leading producer of quality Sauvignon Blanc (Lewis, 2004; Hayward and Lewis, 2008). The debate raised questions about the production and stability of reputation, the value and ownership of collective reputational assets, and the quality of bulk wine, and stimulated calls for tighter quality standards. Six years of rapid growth, corporate reorganisation and industrialisation later, a bumper 2009 vintage and tightening global markets stimulated a new wave of bulk exports to Australia and the UK and a similar set of debates (Holden, 2010; Hembry, 2012).

Discourses of quality associated with provenance narratives have long been at the centre of value creation in wine, in terms of brand development and marketing as well as prescriptive regulatory regimes such as the French Appellation D'Origine Controllee (AOC) (Gade, 2004; Moran, 1993a). In less public and more mundane realms, discourses of quality are also implicated in practices of governance. For over 20 years differential pricing for prescribed grape qualities and economies of sentiment associated with industry identities have been used to encourage NZ grape growers to improve viticultural practices and manage yields to produce particular qualities in the fruit they on-sell to wineries and to restrict yields. At these and other points along the value chain from the vineyard to the social experience of consumption, the idea of quality 
mediates exchanges, orders practices, categorises products, and infuses experiences with meanings.

In this paper we examine quality as a governmentalising and value generating discourse (see Vaudour, 2002). Rather than contributing to debates over whether the quality of wine can be measured or should be understood on a more contingent basis as a matter of personal preference, we explore how quality is composed and ask what work it performs in wine economies. We make two arguments. First, that quality is governmentalising, by which we mean not only that it is implicated in governance or the mechanisms by which political economies are coordinated (Lewis et al., 2002), but also that it provides a basis for understanding relations and helps to order the exchange of symbolic, political and economic values along supply chains (Ponte, 2009; Heller, 2006; Mather 2004) and secure coordination at a distance (Rose, 1999). Second, and as a result, we argue that it is central to the creation, mediation and realisation of economic value in a cultural and experiential good such as wine (Smith Maguire, 2010). That is, quality has not only become an idealised outcome of production, it has also been translated into regimes of governmentality, through constellations of expertise dedicated to producing and valorising knowledges and practices of quality (Callon et al., 2002; Dean, 1999; Rose, 1999). Importantly in wine economy, notions of quality are deeply entangled in relations of, and references to, place (Barham, 2003; Lewis, 2011).

All this means that instead of asking questions like 'what is the quality of the wine in the "bag-in-a-box" or today's "bag-in-a-boat"?', and so reproducing 'quality' as simply some form of ungrounded marker towards which wine either trends or from which it, we ask 'why are debates about quality so prominent and so polarising?'. These questions may help us to develop more revealing ways of thinking about collective reputational assets and more appropriate ways of regulating their appropriation. We create the space for this by tracing the genealogy of contemporary meanings of wine quality, and examining the productive role of these meanings and their related practices in constituting NZ's wine industry.

\section{A genealogy of quality in wine economy}

For the best part of two millennia, the vast majority of the world's wine production was 'ordinary' wine made to supply the everyday cultural practices of local communities (Unwin, 1991). Wines with a reputation for 'quality' were the preserve of social elites, and usually differentiated by reference to the name of a village or region (Barker, 2004). In recent times, however, notions of quality have expanded geographically and across the gamut of wines, fracturing the distinction between 'ordinary' and 'quality'. Production and consumption of ordinary wine have plummeted in much of Southern Europe and South America, where it has long been an integral aspect of everyday life (Hussain et al., 2009); but a new wine culture has flourished in wealthy societies. New economies of wine have developed animated by more complex notions of quality and 'quality indicators' that make claims about distinctive vinous qualities, attach symbolic values to wines that enrich the hedonic and cultural experiences of consumption, and entangle wine in circuits of meaning making (Allen \& Germov, 2011). Place of origin is wrapped into carefully cultivated imaginaries of place, which are linked in different ways to variety, producer brand, and price. Notions of quality differentiate wine by price, segment markets, and organise relations along value chains from vineyard 
decisions about variety and yield to arrangement on retail shelves and discussions about wine at dinner tables. They create economic values over which actors struggle.

In Bourdieusian terms (Bourdieu, 1984), this quality complex frames (more or less discursively and/or institutionally) and enlivens a field of capital exchange, in which actors articulate, mobilise, leverage, struggle over, and exchange reputational, symbolic and economic values. At stake is social status in myriad contexts (Smith Maguire, 2010), reputations of multiple actors and the economic rents associated with them (Overton et al., 2012), and profits from winning trading games in supply chain exchanges (Ponte, 2009). Contests in this field are framed by indicators such as price points, wine awards, and reputations of winemaker, producer and region, regulated by legal definitions of qualities (including geographical indications), and mediated by wine media commentaries, producer promotional campaigns, and wine labels (Barker, 2004). At the heart of this complexity lies wine culture's 'master discourse' of terroir (Lewis, 2011), the understanding that the wines produced in a place express unique flavours attributable to the biophysical environments in which grapevines are grown, the way they are grown, and how wine is made from those grapes. That is, wines express their biophysical environments and the cultural practices of their production, which are linked by processes of learning about winemaking in place (Moran, 2001). Often reduced to a shorthand language of environmental determinism (Moran, 2006), discourses of quality are tied directly to place and monopoly rents (see Harvey, 2001; Overton, 2010).

7 Geographical names have long been used to represent regional traits and qualities in wine. As far back as the Phoenicians and Greeks, wines have been differentiated by geographical naming and references to place of origin (Johnson, 1989; Unwin, 1991). In Europe, the $17^{\text {th }}$ century invention of the wine bottle secured the division of wine into light ordinary wines consumed young and in large quantities by the lower classes, and darker, fuller wines of quality that could be stored (Unwin, 1991). With storage, a small number of elite regions were able to build and secure widespread reputations for quality wines, notably the French regions of Bordeaux, Burgundy, and Champagne. The distinction between ordinary and quality wine was later enshrined in laws passed to deal with fraudulent representation of origin in the wake of the phylloxera epidemic in the mid to late $19^{\text {th }}$ centuries (Moran, 1993). In France, the ordinary/quality distinction and its relation to place became embedded in the AoC, while in other parts of Europe more tentative laws focused on protecting the names of quality wine regions (Barker, 2004). Place positioned wines on an axis of quality, mobilising and entrenching the notion of terroir.

Outside Europe, indicators of wine quality developed differently. Quality in wine was registered in the names of high status old world regions, and social status was conferred by consuming wines imported from them. The colonisers of the British new world took with them no production knowledge or ordinary wine culture. While good wines were at times produced by settlers from Europe's wine regions, these were rarities and producers used the names of European wine regions to connote quality and compete at the edges of the wine-quality-status field. From the 1970s, however, in what proved to be a decisive innovation, they began increasingly to use varietals to label their wines, most notably the vitis vinifera varieties associated with French wines (Barker, 2004; Anderson, 2004). 
9 Parallel initiatives by non-European producers to claim recognition for the quality of their wines, included the watershed "Judgement of Paris" tasting of 1976, when French experts judged Californian Cabernet Sauvignon and Chardonnay wines superior to the finest examples of Bordeaux and Burgundy in a blind tasting. The results were seized upon by the international press ' ... at a moment when the world was ready to be converted' (Loftus, 1985, p. 120). They put Californian wines (and by extension other new world wines) on a quality map, for domestic consumers and international markets. As recognition of non-European wines grew, 'New World' regions began to develop reputations that allowed their qualities to be communicated through the discourse of terroir (Beverland, 2005). Wine regions such as Coonawarra (Cabernet Sauvignon), Central Otago (Pinot Noir), Napa Valley (Zinfandel), and Marlborough (Sauvignon Blanc) have developed reputations associated with grape varieties, which are now also protected by Geographical Indications laws and regulations (Barker, 2004; Banks and Sharpe, 2006).

10 In Europe, the spread of knowledge and technology meant that the baseline flavour/ aroma qualities of table wines were improved, blurring the boundaries between undifferentiated table wine and quality wines and challenging the historical monopoly of the elite regions. In France, a new table wine category called vin de pays now indicates improving table wine regions, and has accommodated the spreading practice of varietal labelling (Barker, 2004). New quality indicators have thus eroded the binary division between quality and table wine, creating instead a more complex field of differentiated values and segmented markets. Wine brands, new regional reputations, varietal labelling and related strategies to valorise them in production, distribution, sale and consumption have transformed the quality field.

11 More transparent ways of indicating quality have demystified wine and made it more accessible to new consumers not schooled in the quality associations and unfamiliar names of appellations. A new knowledge of wine now fosters its own quality narratives such as the fruity, reliable, and value-for-money wines of the new world (Hussain et al., 2009). Enabled by technological advances, these wines have developed styles and related notions of quality that have in effect fashioned their own value complex of industrial producers, marketeers, large retailers, and a new generation of mass consumers educated to be more universal in their tastes by a popular wine media supported by promotional material and universal and universalising cues such as wine awards (Ponte, 2009).

12 As this mass wine culture has expanded, wine has become a significant FMCG for major retailers. Branded difference among wines offers supermarkets a platform for competitive promotional campaigns, implicating them in the production of this new quality complex. They have introduced new producers, regions and varieties to consumers to attract consumers to their stores, with the promise of difference for value. Yet at the same time their demands for high volume and low price wines have exerted a standardising and industrialising influence over wine production that stimulates and rewards consistency and familiarity. These new conceptions of quality for mass consumers have yielded a qualitative hierarchy signified by varietal and brand that is supposedly based on consistent consumer expectations at particular price points (see Berthomeau, 2001; Paul, 2002). The rationalisation and consolidation of producers has followed (Anderson, 2004). 

new paradigm of quality (Smith Maguire, 2010). The shift to large-scale consumption has, if anything, added new gloss and lines of social and spatial expansion to the exclusivity of provenanced wines. Even within the supermarket, the consumer is exhorted to be discerning and interested in place, variety, and difference, just as she is being constituted as universal by mass wines. Smaller and elite producers still emphasise provenance as a distinctive quality indicator, and elite regions maintain terroiriste claims to enhance and valorise the symbolic and material qualities of their wines. These claims develop producer-defined understandings of quality that are fostered and framed in the vineyard and winery, reworked through experimentation in production, materialised in wine styles, elaborated by wine writers and valorised through exclusivity, artisanship and artistry as tropes of social status in wine consumption. colour to narratives about taste and wine awards. At its more cerebral and critical ends, it is implicated in the constitution of a different quality complex to that of mass wine consumption. Writers refer to practices in the vineyard and winery, analyses of aroma profiles, and the details of place, terroir and winemaking enterprise (see for example Johnson \& Robinson, 2008). The 100 point rating system pioneered by US wine critic Robert Parker scores wine quality and recasts quality assessment as a competitive playing field. Widely cited by the wine media, consumers respond to these signals and producers now make wines in styles that they hope will find favour with Parker, other influential wine critics, or in wine competitions more generally. This standardising technology is at work on top end wines, but translates into mass wines via the less precise quality metrics of wine awards, which exercise a more pervasive influence that extends to high volume wines and yields stickers that give strong visual quality cues on crowded shelves (Landon \& Smith, 1997). It begins to order the quality complex of status, distinction and taste that gives wine much of its value (Origgi, 2007).

The transformation of wine quality has thus been complex (see Smith Maguire, 2010). Terroiriste and mass constructions of quality coexist and are co-constituted by practices such as wine awards and the development of second labels and other creative practices by producers in the winery and vineyard to leverage across the symbolic and economic values of mass and high-end wines. Brand collateral and media commentaries suspend the contradictions and enhance the value creating potential of this complex. Both are underpinned by an expansion of general and specific wine knowledge from production to consumption, driven by brand promotion, wine media, and the work of multiple other actors including tourism marketers, wine judges, supermarket buyers, yeast researchers, and environmental auditors. This quality complex draws meanings from geographical knowledge in wine, from the origins of the wine to its biography and its travels from sites of production to consumption, the social and environmental relations embedded in its production, and the meanings of place evoked through its consumption (Cook \& Crang, 1996). This knowledge is embedded in wider geographical imaginaries and socio-political projects that connect considerations of quality to social dynamics. In contemporary times, these include the 'quality turn', a product of postmodern consumption aesthetics and the rise of alternative food movements associated with local foods, environmentalism, and fair trade as well as food safety (Goodman, 2003). The quality turn gives extra impetus to place-based conceptions of quality such 
as terroir, and opens opportunities to infuse them with the values of place-bound relationships between people and wine.

Our genealogy, which stretches from the Phoenicians to the quality turn, portrays wine quality as socially constructed, in relation to both terroir and the political economy of value creation. Notions of quality in wine are unstable, contested and contradictory, and are constructed in part beyond industry circuits or marketing interpretations of consumer behaviour. Wine economy is firmly embedded in wine culture and wider socio-cultural circuits (Origgi, 2007). Social status and its relations to difference and place as signifiers of exclusivity are crucial dimensions. Quality is, however, also a governmental rationality that is productive of the wine economy and culture that give rise to and shape them. In what follows we examine how particular actors have intervened in this complex to steer NZ's wine economy at a particular time in its development. We show how quality has been incorporated into technologies of government that seek to shape the subjectivities, practices, and the spaces of NZ wine, and have performed a quality industry into place.

\section{The Rationality of Quality in the New Zealand Wine Industry}

17 In the permissive regulatory regimes of neoliberal New Zealand much of the burden for regulating the wine economy falls on the industry itself (Barker et al., 2001), which draws heavily on a rationality of quality to impose technologies of government that shape the conduct of actors. The key technologies we identify are: associational governance, nation branding, and contracts. These are not the only technologies of government acting on the NZ wine economy, and nor are they the only technologies of government through which quality works (see, for example, Overton and Heitger, 2008 on appellations), as we outline above. Our point is that they deploy understandings of quality to shape and structure the industry, and that they elicit an ethical dimension to the NZ wine industry that is scaled at the national level. We go on to argue that this is often at odds with practices focused on short term profitability, solvency and competitiveness at an individual winery such that this rationality of quality is precarious.

\section{Quality and associational governance}

18 The institutional centre of the NZ wine industry is New Zealand Winegrowers (NZW), which represents grape growers and winemakers (Barker et al., 2001). NZW was established in 2002 through a merger of the New Zealand Grape Growers Council (NZGGC) and the Wine Institute of New Zealand (WINZ), which are funded through legislated levies on grape and wine sales. As a result, all NZ's grape growers and wine makers are automatic members with voting rights. NZW's state sanction and the active leadership role have positioned it towards the centre of the industrial order and given it a key role in the governance of the sector (Lewis, 2008; PWC 2011). It offers stewardship over Brand NZ Wine and NZ Wine Inc (the collective interests of the industry) and supports members in the domains of marketing, regulation (lobbying and compliance), and knowledge product and dissemination (research), and has been held 
up as an exemplar for an industry body in a permissive regulatory environment (Barker et al., 2001; Lewis, 2008; PWC, 2011).

NZW's capacity to occupy this position attests to the successful resolution of earlier struggles within WINZ over representation and between growers and wineries over grape prices. The accommodation is built on both a cleverly conceived representational structure (Barker et al., 2001), and a discourse of quality that recognises, celebrates, and promotes mutual interests in a reputation for quality wine. Grape grower and winery interests are aligned through the emphasis that the new quality paradigm places on interdependency, evocatively expressed in the aphorism that 'great wines are made in the vineyard'. Quality is also seen as the glue that seals a symbiotic relationship between small terroiriste winemakers who draw interest from the wine media, attract wine tourists and win awards, and the larger volume wineries that secure presence in markets and attract broader attention. All are presumed bound by mutual interests in and collective ownership of New Zealand's reputation for quality. The formation of NZW was sealed by a jointly issued vision statement from the Chairpersons of WINZ and NZGGC: 'for New Zealand wine to be internationally recognised as the leading producer of premium quality wines' (Hubscher \& Crosse, 2002).

The front page of NZW's website contains a four minute video under a link titled 'About Us' which delivers a strong message of NZ's quality focus and ties quality to place by blending sun-drenched natural landscapes with 'winescapes' of vineyards and wine production centres. Our point is that this is not just the marketing ploy of an established organisation: rather, this discourse of quality underpinned its establishment and the framing of shared interests, aspirations and identity necessary to bring competing interests under the same banner. The rationality of quality enabled associational governance to take place.

The emphasis on quality has also underpinned NZW's response to concerns about production levels of Marlborough Sauvignon Blanc. NZW's 2010 Annual Report insists that 'even in testing times, the need to produce wines of the highest quality is nonnegotiable' (NZW, 2010, p. 7) and emphasises the threat posed to national reputation ('the industry's greatest asset') by unbranded, below-cost wines and free-riders (NZW, 2010, p.5). NZW has endeavoured to talk down production levels through moral suasion so as to protect quality and reputation (Carpinter, 2010). The Chair's Report in the 2010 Annual Report reiterates NZW's 'unswerving commitment' to quality as a platform for future development and points to a 'well managed, high quality 2010 vintage' to infer the success of the strategy of talking down yields to achieve the balance between supply and demand necessary 'for our sector to prosper as a quality producer' in 2010 (NZW, 2010, p. 4). This understanding of quality is rooted in established production and end-user notions, but is also being tacitly codified and developed technically through codes of practice. Perhaps the two most significant are, the Wine Standards Management Plan (WSMP) and Sustainable Winegrowing New Zealand (SWNZ). NZW lobbied for and cooperated closely with government in developing the Wine Act (2003), which collated the different legislation governing practice in the wine industry under a single Act and mandated that all winemakers operate under a WSMP. NZW then cooperated with the agency administering the Act to develop a template WSMP for members that would help them comply with the requirements of the Act (Bell Gully, 2007). SWNZ is a programme of sustainable winegrowing and winemaking protocols that foster vineyard 
and winery practices that will stand up to international environmental audits. It was designed to 'enhance the reputation of the NZ industry as a source of premium quality wines produced with true environmental integrity' (NZW, 2004, p. 17). Environmental integrity is seen as adding new values to quality narratives as well as experimenting with new value propositions (Flint \& Golicich, 2009). From 2012 all wineries are expected to be members of an accredited environmental standards plan, although, as with NZW's WSMP template, producers are able to adopt their own plan and third party auditor.

Both sets of standards are based on audit technologies that rely on producers regulating themselves. Neither is framed explicitly by NZW as a set of quality standards, but both are designed to protect and enhance New Zealand's reputation as a quality producer. The point is an important one, as the discourse of quality as a force of suasion and self-governance and an implied market discipline cannot be seen to equate to an imposition of material standards by an industry or other regulatory body. It is vulnerable to any sense of external determination. So while NZW describes SWNZ as designed to enhance NZ's reputation for quality, and third party auditors of WSMP advertise themselves as being 'serious about quality' (Wineworks, 2012), NZW avoids expressly linking WSMPS or SWNZ to quality standards. Nonetheless, they are part of the regulatory architecture of a quality industry. Both provide producers with information to feedback into enhanced quality standards in production through supply chain management, benchmarking and best practice protocols (Flint \& Golicich, 2009), which are intended to instigate aspirational activity around particular codified knowledges of quality and bring vineyard practice into line with them. Larger companies recognised at an early stage SWNZ's potential as a management tool to standardise and control practices in their vineyards and among contract growers.

By speaking 'quality', often through content provided to industry journal The New Zealand Winegrower and supported by commentaries from deeply embedded media (see for example Cooper, 2008), NZW is not just trying to create positive associations for its wines; it is providing a point of shared identity, aspiration and interest. The agreed commitment to quality mediates marketplace competition and the antagonisms of supply chain relations (Lewis, 2008). Instead, it provides a governing identity and a collective interest centred on association and backed by standards and practices.

\section{'Brand New Zealand Wine'}

Commitment to quality also underpins NZW's collective marketing and promotion and its management of collective reputational assets via the concept of 'Brand NZ Wine'. Developed in association with government economic development agencies in the mid-1990s, WINZ eventually deployed the slogan 'The Riches of a Clean Green Land'. New Zealand wine has since been rebranded as 'Pure Discovery' to deemphasise the underlying environmental elementalism and green marketing overtones of 'Riches'. 'Pure Discovery' aligns more closely with NZ's two most prominent nation branding campaigns the tourism ' $100 \%$ Pure' campaign and the cross-sectoral 'New Zealand New Thinking' campaign that aims to extend and complement NZ's landscape-centred imagery by emphasising it as a place 'where innovative, creative and technologically advanced ideas are pursued' (Lewis, 2004, 2011). 
Like 'Riches', 'Pure Discovery' emphasises quality by focusing on the uniqueness of NZ winescapes, the diversity and intensity of experiences, and the human characteristics of 'innovative pioneering spirit' and 'commitment to quality' (Lewis, 2008). It is designed to provide a national umbrella of quality association under which regional and company brands can pursue particular terroiriste or mass quality claims. The nationally scaled marketing campaign links actors in the NZ wine industry to wider national imagery and provides economies of scale in advertising. Behind the brand, as with 'Riches', Winegrowers has organised a national level marketing programme, the NZ Wine Generic Promotional Campaign (NZGPC). The NZGPC also places quality at its centre, stating that its role is to foster the vision of NZ as the "leading producer and marketer of premium quality wines' (NZW, 2003, p. 13). The campaign has included hosting wine events and seminars in key export markets, domestic promotion, the annual Air New Zealand Wine awards, and the cultivation of long-term relationships with key intermediaries such as wine writers and major retail buyers (Hall \& Mitchell, 2008). These are in themselves investments in the technologies, architecture and practices of quality; investments in making and demonstrating quality.

Brand NZ wine produces a quality identity that names, frames and reinforces the notion of collective interests in the production of quality products. The quality recognition being developed is not just amongst wine buyers but also amongst NZ wine producers. This programme of identity construction is expressed in the aphorism 'great wine is made in the vineyard', which emphasises quality in production and shared interests in it. The associational governance and promotional activities of the industry come together under NZW where they work to form and reproduce the identity of the $\mathrm{NZ}$ wine industry as one dedicated to the production and marketing of quality wine. This is deeper than a superficial gloss covering an economically rational and commodity driven grouping of enterprises. It contributes to the shaping of the subjectivities of the participants, whether this is the small-scale producer attracted to the romance of producing their own quality wine label or the hard-headed major label producer looking to penetrate overseas markets with a reliable source of differentiation, and provides them with the will and the skills to adopt the necessary practices and behaviours for producing quality wine, as well as the symbolic capital for selling it.

\section{Contracts}

The rationality of quality has been translated into many of the more mundane practices of research and public relations. NZW's research programme is framed as research into quality and legitimated by the need for a thorough understanding of the environments, varieties and techniques... [necessary to secure NZ]... as a leader in the quality stakes' (NZW, 2010, p. 7). The two key sites of economic exchange within the industry, the distribution contract or final sale and the grape supply contract, are governed by the rationality of quality. The quality framing of the first is discussed above, but the second is increasingly regulated by quality clauses. Supply contracts typically consider some combination of precisely what and how much is to be supplied and from where, pricing and payment arrangements, vineyard management, harvesting arrangements, insurance issues, quality requirements and measurement issues, rights of refusal, and penalties (Zylbersztajn \& Miele, 2005; Odorici \& Corrado, 2004). Long-term contracts can be simpler, but will still differentiate among grape 
qualities and attempt to induce and reward the growing of grapes of particular qualities.

Again, these contracts are not just neutral technologies in the background of the more important moment of transaction. They have the power to shape conduct on a longer timescale by creating expectations around grape quality that have consequences for vineyard management practice across multiple years. Alongside NZW's research and education programmes, contracts that emphasise quality production have shaped winemaker and grape grower subjectivities at the level of practice.

\section{Quality in industry governance}

The rationality of quality is thus central in each of these three spheres of industry governance, but is not forced on the NZ wine industry by fiat. Rather, it is achieved 'at a distance' (Rose, 1999) through acting on the subjectivities of grape growers and winemakers, and not necessarily in an orchestrated manner. Unlike most wine quality signifiers, which are scaled at the level of the individual winery or the region, NZ's quality signifier is scaled at the national level. Unfortunately, this combination of permissive governance and national scaling can be undermined by individual wineries choosing to produce cheap bulk wine or to produce lower quality wine that still leverages off NZ wine's quality associations. Further, in a permissive regulatory regime, this cannot be remedied by the application of explicit quality standards by an industry or government authority. The quality discourse is thus doubly precarious.

31 This takes us back to the debates with which we started and the questions of collective assets, free-riders and shared fates. Our account of the governmentality of quality suggests that there is more at play in NZ's wine economy than naked political economy. We identify an ethical dimension, which is most apparent when breeched. While someway short of Adam Smith's notion of moral sentiments and Sayer's (2007) revival of interest in moral economy, we identify an ethic of quality attached to the mystique of terroir, artisanship, and passions for wine that have been long argued to enervate wine economy (Charters, 2006). Our account of this ethic as a governmentality does not fully reveal its productive force in the way an ethnography of wine enterprise and its subjects may have done, but we are able to highlight its work in building identity and in shaping the choices of actors in the absence of prescriptive regulation, especially with regard to reputational commons.

\section{Conclusion}

In this paper we have approached quality as an idea that is not pre-existent or selfexplanatory, but the subject of a set of dynamic discourses associated with the political, environmental, economic and social positionality of wine. By taking a genealogical approach to the notion of quality in wine economy we have highlighted the ways it has been attached to various ideas about place, variety, geopolitics, national politics, labelling and so on, and how these have evolved over time. We have looked at some of the ways through which the NZ wine industry has evoked quality in constructing an identity for itself and mobilised it in various technologies of government, which will produce quality focused subjects and induce quality focused practices. The point is that 
the rationality of quality is vital in the structuring of the NZ industry as it impacts upon workplace practices, business strategies and industry relationships.

The insertion of technologies of quality into wine production practices reinforces the deprioritisation of 'normal' business practice that already exists within some parts of the wine economy with its romantic associations and notions of winemaking as an art form. This is exemplified by bag-in-a-box and bag-in-a-boat strategies where no illegality is committed by those pursuing business objectives of profit-maximisation, but where the protagonists have been named and shamed as damaging the industry. But this is no mere preciousness. Significant investment has been made in promoting the ascendancy of the rationality of quality over other business imperatives. This is realised in the building of a generic brand with strong associations in the marketplace and the fact that debates about overproduction and free-riding have been conducted around notions of quality. Indeed, for small enterprises, as is arguably the case for most of the larger ones, quality is a business imperative (see PWC, 2011). Industry participants fear that 'rent-raiding' of Brand NZ Wine (Lewis, 2004) could undermine not only their future profits but the relationships, shared practices, sociality and concomitant trust they have built up in the industry over time.

However, the practice of bulk-exporting confirms that the nationally-scaled rationality of quality governing the NZ industry is precarious. Critics of bulk wine exporting are now suggesting that the mutual interests between grapegrowers and wineries and among wineries of contrasting size have been eroded to the point where the governance structure of NZW has become a barrier to pursuing mutual interests (see Hembry, 2012). While backed by demonstrable long-term self-interest and an architecture for quality practice embedded in associational governance, ethics of trust, the commons and passions for wine, these have only minimal regulatory force and are vulnerable to short-term self-interested, morally hazardous behaviour. There is an argument that the rapid growth of the NZ industry meant profits have been relatively easy to come by and ethics of collectivity have been relatively untested. As markets mature and pressure comes on the need to shift wine in whatever way possible and NZ producers are forced to pursue conflicting interests and/or compete more aggressively with each other, this ethical economy has come under pressure. It has also come under pressure from changes in the composition of the collective through increasing overseas ownership and the increasing dominance of corporate capital more generally. In such conditions, where shareholder returns can be managed more effectively through high volume low profit wine commodity exporting, mutual acquiescence to the rationality of quality may become untenable.

As a final conclusion, we wish to re-assert two general points directed at two different general audiences. First, to analysts of industry at any scale, we believe this analysis shows not just the importance of ideas and ideologies in the structure of an industry, but the importance of how those ideas are understood, contested and mobilised through various tactics and technologies of government and governance. Focusing on the seemingly neutral measures of supply and demand almost inevitably produces a reading of an industry structure that is biased towards notions of consumer sovereignty and dismissive of the gamut of emotions and relations inherent in production. Thinking about the way an industry has been governmentalised offers a more nuanced understanding of supply chain relations and the sociality of productive activities. And second, to participants in the NZ wine industry, the future viability of 
the generic NZ brand and the intellectual property wrapped up in it remain exposed to rent-raiding activity. Performing meekly within the quality discourse may no longer secure the quality rationality and that which it protects. This means either accepting the risk, fortified perhaps by the argument that links between such activity and the value of the intellectual property of the brand are unproven or that bulk wine exporting may in actual fact introduce new consumers to $\mathrm{NZ}$ wine, and bolstering the discourse by rhetorical interventions; or acting decisively by, for example, overturning the permissive regulatory regime to impose quality standards, or seeking out a clever means of distinguishing between two NZ quality industries, one of high and one of mass quality. Any response, however, poses the risk of upsetting the fine balance of diverse interests and commitments that hold associational governance together. What is likely is that the centrality of the rationality of quality in the $\mathrm{NZ}$ wine industry will remain under question.

\section{BIBLIOGRAPHIE}

Allen M., Germov J., 2011. Judging taste and creating value: The cultural consecration of Australian wines. Journal of Sociology, $n^{\circ} 47$, p. 35-51.

Anderson K. (ed.), 2004. The World's Wine Markets: Globalization at Work. Edward Elgar, Cheltenham. Banks G., Kelly S., Lewis N., Sharpe S., 2007. Place 'from one glance': the use of place in the marketing of New Zealand and Australian wines. Australian Geographer, n 38, p. 15-35.

Banks G., Overton, J., 2010. Old world, new world, third world: Reconceptualising the worlds of wine. Journal of Wine Research, $n^{\circ} 21$, p. 57-75.

Banks G., Sharpe S., 2006. Wine, regions and the geographic imperative: The Coonawarra example. New Zealand Geographer, $\mathrm{n}^{\circ}$ 62, p. 173-184.

Barham E., 2003. Translating terroir: the global challenge of French AOC labelling. Journal of Rural Studies, $n^{\circ} 19$, p. 127-138.

Barker J., 2004. Different worlds: law and the changing geographies of wine in France and New Zealand. Unpublished PhD thesis University of Auckland.

Barker J., Lewis N., Moran W., 2001. Reregulation and the development of the New Zealand wine industry. Journal of Wine Industry Research, 12(3), p. 199-222.

Bell Gully, 2007. Winegrowers' Legal Guide. Available from http://www.bellgully.co.nz/ Newsletters/Winegrowers_2007/index.asp

Berthomeau J., 2001. Comment mieux positionner les vins français sur les marchés d'exportation? Ministère de l'Agriculture, Paris.

Beverland M., 2005. Crafting brand authenticity: the case of luxury wines. Journal of Management Studies, $\mathrm{n}^{\circ}$ 42, p. 1003-1019.

Bourdieu P., 1984. Distinction: A Social Critique of the Judgement of Taste. Abingdon, Routledge Kegan and Paul. 
Callon M., Madel C., Rabeharisoa V., 2002. The economy of qualities. Economy and Society, $\mathrm{n}^{\circ}$ 31, p. $194-217$.

Carpinter B., 2010. Drinkers gain from wineries' pain, Stuff.co.NZ (http://www.stuff.co.nz/ business/farming/4181044/Drinkers-gain-from-wineries-pain ) last access 8/04/2013

Charters S., 2006. Wine \& society: The social and cultural context of a drink. Oxford, Elsevier.

Cook I., Crang M., 1996. The World On a Plate Culinary Culture, Displacement and Geographical Knowledges. Journal of Material Culture, 1(2), p. 131-153.

Cooper M., 2008. Wine Atlas of New Zealand. Auckland, Hodder Moa.

Dean M., 1999. Governmentality: Power and Rule in Modern Society. London, Sage.

Flint D., Golicic S., 2009. Searching for competitive advantage through sustainability: A qualitative study in the New Zealand wine industry. International Journal of Physical Distribution and Logistics Management, $\mathrm{n}^{\circ}$ 39, p. 841-860.

Gade, D., 2004. Tradition, Territory, and Terroir in French Viniculture: Cassis, France, and Appellation Controlee. Annals of the Association of American Geographers, ${ }^{\circ}$ 94, p. 848-867.

Goodman D., 2003. The quality 'turn' and alternative food practices: reflections and agenda. Journal of Rural Studies, n 19, p. 1-7.

Hall M., Mitchell R., 2008. Wine Marketing: A Practical Approach. Oxford, Butterworth Heinemann Harvey D., 2001. Spaces of Capital, Ch18: The art of rent: globalization and the commodification of culture. Edinburgh, Edinburgh University Press.

Hayward D., Lewis N., 2008. Regional dynamics in the globalising wine industry: the case of Marlborough, New Zealand. Geographical Journal, n 174, p. 124-137.

Heller C., 2006. Post-industrial 'quality agricultural discourse': Techniques of governance and resistance in the French debate over GM crops. Social Anthropology, 14 (3), p. 319-334.

Hembry O., 2012.Wine war: Quality v quantity. New Zealand Herald, 31/03/12 http:// www.nzherald.co.nz/business/news/article.cfm?c_id=3\&objectid=10795631

Holden K., 2010. Kiwi, still king? Drinks Trade, n 17, p. 34-40.

Hubscher P., Crosse W., 2002. Chair's Report. New Zealand Winegrowers Annual Report. Auckland, New Zealand Winegrowers.

Hussain M., Cholette S., Castaldi R., 2008. An Analysis of Globalization Forces in the Wine Industry: Implications and Recommendations for Wineries. Journal of Global Marketing, $\mathrm{n}^{\circ} 21$, p. 33-47.

Johnson H., Robinson J., 2008. The World Atlas of Wine. London, Octopus Publishing Group.

Landon S., Smith C., 1997. The use of quality and reputation indicators by consumers: the case of Bordeaux wine. Journal of Consumer Policy, n² 20, p. 289-323.

Lewis N., Moran W., Barker J., Perrier-Cornet P., 2002. Territoriality, enterprise and réglementation in industry governance. Progress in Human Geography, 26(4), p. 433-462.

Lewis N., 2004. The New Zealand wine industry: issues and status at vintage 2004, WIRI-NZTE Wine Industry Research Project. Auckland, Auckland Uniservices Ltd.

Lewis N., 2008. Constructing economic objects of governance: The New Zealand wine industry. In Le Heron R. \& Stringer C. (eds.), Agri-Food Commodity Chains and Globalising Networks, Aldershot, Ashgate, p. 103-120. 
Lewis N., 2011. Packaging Political Projects in Geographical Imaginaries: The Rise of Nation Branding. In Pike A. (ed), Brands and Branding Geographies, Cheltenham and Northhampton, Edward Elgar Publishing, p. 264-288.

Loftus S., 1985. Anatomy of the Wine Trade. London, Sidgwick and Jackson.

Mather, C., 2004. Codes of conduct/retailer buying practices and farm labour in South Africa's wine and deciduous fruit export chains. International Development Planning Review, $\mathrm{n}^{\circ} 26, \mathrm{p} .477-$ 493.

Moran W., 1993. The Wine Appellation as Territory in France and California. Annals of the Association of American Geographers, n 83, p. 694-717.

Moran W., 2001. Terroir: the Human Factor. The Australian and New Zealand Wine Industry Journal, $n^{\circ} 16$, p. $32-51$.

Moran W., 2006. Crafting terroir: people in cool climates, soils and markets. International Cool Climate Symposium, Christchurch, 6-10 February 2006.

Moran W., 2000. Culture et nature dans la geographie de l'industrie vinicole Neo-Zelandaise. Annales de Geographie, $\mathrm{n}^{\circ}$ 614-615, p. 525-551.

New Zealand Winegrowers (NZW), 2003. New Zealand Winegrowers. Auckland, New Zealand. New Zealand Winegrowers (NZW), 2004. New Zealand Winegrowers. Auckland, New Zealand. New Zealand Winegrowers (NZW), 2010. New Zealand Winegrowers. Auckland, New Zealand. Odorici V., Corrado R. 2004. Between supply and demand: intermediaries, social networks and the construction of quality in the Italian wine industry. Journal of Management and Governance, 8(2), p. 149-171.

Origgi G., 2007. Wine epistemology: The role or reputation and rating systems in the world of wine. In Smith B. (ed.), Questions of Taste, Oxford, Oxford University Press, p. 183-197.

Overton, J., 2010. The consumption of space: land, capital and place in the New Zealand wine industry. Geoforum, n 41, p. 752-762.

Overton J., Heitger J., 2008. Maps, markets and Merlot: The making of an antipodean wine appellation. Journal of Rural Studies, $n^{\circ} 24$, p. 440-449.

Overton J., Murray W., Banks G., 2012. The Race to the Bottom of the Glass? Wine, Geography, and Globalization. Globalizations, $n^{\circ}$ 9, p. 273-287.

Paul H.W., 2002. Science, Vine and Wine in Modern France. Cambridge, Cambridge University press.

Ponte S., 2009. Governing through Quality: Conventions and Supply Relations in the Value Chain for South African Wine. Sociologia Ruralis, n 49, p. 236-257.

Price Waterhouse Coopers (PWC), 2011. New Zealand Winegrowers Strategic Review. PWC Auckland.

Rose N., 1999. Powers of Freedom: Reframing Political Thought. Cambridge, Cambridge University Press.

Sayer A., 2007. Moral Economy as Critique. New Political Economy, 12, p. 261-270.

Smith Maguire J., 2010. Provenance and the liminality of production and consumption: The case of wine promoters. Marketing Theory, $\mathrm{n}^{\circ}$ 10, p. 269-282.

Tipples R., 2008. Cottesbrook's New Zealand Sauvignon Blanc wine to Tesco. British Food Journal (Special Issue 'Relationships, Networks and Interactions'), 110 4/5, p. 444-473. 
Unwin T., 1991. Wine and the Vine: An Historical Geography of Viticulture and the Wine Trade. London and New York, Routledge.

Vaudour E., 2002. The Quality of Grapes and Wine in Relation to Geography: Notions of Terroir at Various Scales. Journal of Wine Industry Research, $n^{\circ} 13$, p. 117-141.

Wineworks, 2012. Certifications http://www.wineworks.co.nz/certifications/, last accessed $8 / 04 / 2013$.

Zylbersztajn D., Miele M. 2005. Stability of contracts in the Brazilian wine industry. Revista de economia e sociologia rural, $\mathrm{n}^{\circ}$ 43, p. 353-371.

\section{RÉSUMÉS}

La notion de "qualité" est tout autant inhérente à l'économie vinicole qu'aux économies culturelles. Il est donc possible d'identifier les qualités objectives, subjectives et multiples du vin au travers des nombreux profils d'arômes. Dans cet article, nous commençons par étudier les conséquences de l'utilisation généralisée de la notion de qualité, de sa matérialité indéfinie et des technologies de contrôle pesant sur l'économie vinicole. L'exemple de la Nouvelle-Zélande nous permet d'expliquer que la qualité a été utilisée pour soutenir la rente générée par la réputation nationale des vins et de mettre en avant les principales technologies développées pour soutenir l'industrie vinicole dans la création et le soutien de cette réputation. Nous suggérons qu'en tant que gouvernementalité, la qualité est le fondement d'une économie éthique associant la gestion des rentes collectives et la culture du vin, qui par là même, transcende son économie. Cet article a pour principal objectif d'analyser le rôle de la qualité dans la gouvernance de l'économie vinicole néo-zélandaise.

The notion of 'quality' circulates around wine economy as it does many cultural economies. It may be possible to identify objective dimensions of quality in wine by referring to various aroma profiles, but it is both an inherently subjective and multiply qualified conception. In this paper, we begin from the position that one of the consequences of the widespread use and uncertain materiality of quality is that it defines a discursive field within which various technologies of control are brought to bear on the wine economy. We use the New Zealand case to argue that quality has been deployed to support the collective rents generated by a national reputation for quality wine and highlight key technologies developed to organise industry in the creation and support of that reputation. We suggest that as a governing rationality (governmentality) quality enacts an ethical economy associated with ownership of collective rents and a culture of wine that transcends its economy. The paper focuses attention on the work that quality performs in governing the New Zealand wine economy.

\section{INDEX}

Keywords : Governmentality, ethical economy, cultural economy, technologies of control, terroir, provenance

Mots-clés : Gouvernementalité, économie éthique, économie culturelle, technologies de contrôle, terroir, provenance

Thèmes : Sur le Champ - Sur le Terrain 


\section{AUTEURS}

\section{RUSSELL PRINCE}

Russell Prince, r.j.prince@massey.ac.nz, geographer, is lecturer, Massey University, New Zealand. NICOLAS LEWIS

Nicolas Lewis, n.lewis@auckland.ac.nz, geographer, is senior lecturer, University of Auckland, New Zealand. 